\title{
On the relationship between intellectual capital and financial performance: A panel data analysis on SME hotels
}

\author{
Filipe Sardo ${ }^{\mathrm{b}, *}$, Zélia Serrasqueiro ${ }^{\mathrm{a}}$, Helena Alves ${ }^{\mathrm{a}}$ \\ a Department of Management and Economics, University of Beira Interior, Portugal \\ ${ }^{\mathrm{b}}$ Universidade Europeia, Portugal
}

\section{A R T I C L E I N F O}

\section{Keywords:}

Intellectual capital

Financial performance

Small and medium-sized enterprise hotels

Dynamic panel data

\begin{abstract}
A B S T R A C T
This paper analysed the effect of intellectual capital on small and medium-sized hotel financial performance for the period between 2007 and 2015. Using a sample of 934 Portuguese small and medium-sized hotels, this study adopted the GMM system (1998) estimator, to analyse a dynamic panel data. The findings suggested that intellectual capital components, i.e., human capital, structural capital and relational capital provide a positive impact on hotel financial performance. Human capital and relational capital seemed to be key elements for the success of hotels, being the basis of service quality in the hotels sector. Furthermore, the results showed that human capital and structural capital are capitalized by the establishment and maintenance of long-term relationships with key stakeholders. These findings indicated that the interaction between intellectual capital components enhances the hotel financial performance. Herein, it is highlighted the importance of intellectual capital in small and medium-sized hotel financial performance.
\end{abstract}

\section{Introduction}

Resources, such as knowledge and skills (operant resources (OR)), are the foundation stone for competitive advantage (Vargo and Lusch, 2016) and when integrated and exchanged with one another provides a high generated value. Value co-creation (VCC) is therefore the process of integrating and transforming resources that require interaction and imply various network actors (Lusch and Vargo, 2006). In this regard, the greater amount of OR a firm possess the greater is its capacity to cocreate value which enhances its competitive advantage.

Resources are what actors can draw on for support (Lusch and Vargo, 2014), and they are generally classified as operand (i.e., tangible, static resources, such as physical objects) or operant (i.e., usually intangible, dynamic resources that can create value) (Arnould et al., 2006; Constantin and Lusch, 1994; Vargo and Lusch, 2008). OR are not exhaustible but are rather scalable, re-usable, renewable, and creatable, and they are applied in support of the service supply (Lusch et al., 2007).

According to FitzPatrick et al. (2013), intellectual capital (IC) can reflect the kind of OR that a firm can use to create value and innovation. IC is a source of value propositions that allow firms to outstand competitors and enhance firms' financial performance (FitzPatrick et al., 2013) when embed in a VCC network (Tynan and McKechnie, 2009; Vargo and Lusch, 2016). The IC generally contributes for the firms' growth opportunities and value creation (Liu, 2017) and therefore it is considered the core concept of strategic resources to assure firms competitive advantage (Liu, 2017). IC can contribute to answer the changes in customer needs, as well as to respond to the market opportunities (Liu, 2017). Thus, IC has a relevant role for value creation and innovation in the tourism sector, which is a grouping of a variety of interconnected industries, such hotels, accommodation, lodging, transportation, food and leverage industry. There is no tourism product or tourism destination without interconnection of all actors (Macchiavelli, 2001).

Previous studies indicate that the profitability of small and mediumsized (SME) hotels is sensitive to several factors, such as experience, skills, education level of the employees and owners/managers, volatility of revenues, and capital structure decisions (Sharma and Upneja, 2005; Poorani and Smith, 1995; Kaufman et al., 1996; Romer, 1986). An enhanced IC can act as an internal factor that contributes to firms' performance and competitiveness. However, there are few studies focusing on IC as key factor of innovation, competitiveness, and performance in the hotel industry (Bontis et al., 2015; FitzPatrick et al., 2013). Furthermore, according to Marzo and Scarpino (2016), the study of IC in small and medium-sized enterprises has not deserved much attention of researchers. This study attempts to fill these gaps by analysing the impact of IC on the financial performance of SME hotels.

The synergetic value of IC is rooted in the interaction between its

\footnotetext{
* Corresponding author at: Quinta do Bom Nome, Estrada da Correia 53, 1500-210 Lisbon, Portugal.

E-mail address: filipe.sardo@universidadeeuropeia.pt (F. Sardo).
} 
different components (Bontis et al., 2015; Sydler et al., 2014), i.e., human capital (employees' talent, skills and expertise), structural capital (organizational capabilities, culture, processes, patents, copyrights, trademarks, databases) and relational capital (creation and maintenance of relationships with stakeholders). Therefore, this study first research objective is to analyse the relationship between each IC components, i.e., human capital, structural capital and relational capital and SME hotel financial performance. Previous tourism and hospitality literature focuses on how IC improves firm performance (Sainaghi and Baggio, 2014; Zeglat and Zigan, 2014), but there are few studies analysing the inter-relationships among the different components of IC and its effects on hotels' financial performance. Therefore, the second research objective of the current study, is to analyse how the IC components inter-relationships between, human capital, relational capital, and structural capital impact on SME hotel financial performance. Additionally, this study, different the previous studies, using dynamic panel data models, captures the dynamic character of the relationships between IC and SME hotel financial performance.

In Portugal, small and medium-sized enterprises play a vital role in its economy. According to the National Statistical Institute (INE, 2017), small and medium-sized enterprises represent 99,9\% of total business activity, contributing with 59,9\% of total sales in Portugal and employ $79,9 \%$ of total workforce. The sector of Accommodation, Restaurants and similar accounts for a total of 91.826 firms, and the majority of these firms are considered micro-sized ( $89 \%$ of total firms). The remaining firms are considered small and medium-sized enterprises $(10,5 \%$ of total firms), where these employ $46,5 \%$ of the total workforce of the sector (INE, 2017). The accommodation sector accounts for $17,1 \%$ of total firms (1.591 hotels) where Restaurants and similar, contributes with $36,2 \%$ of total sector revenues and employs $26,2 \%$ of total sector workforce (BdP, 2016).

The analysis of IC on Portuguese SME hotel financial performance was performed with data collected for the period between 2007 and 2015. This study resorts to the GMM system (1998) estimator, which allows to consider the heterogeneity of firms and their evolution over time. Therefore, this study uses a dynamic panel data model.

The results obtained reveal that all the components of IC, i.e., human capital, structural capital and relational capital have a positive impact on SME hotel financial performance. Human capital and structural capital appear to be key elements for the success of hotels and are the basis of service quality in the hotel sector. Additionally, human capital and structural capital are capitalized by the establishment and maintenance of long-term relationships with key stakeholders, i.e., relational capital. Structural capital and relational capital in the previous period positively affect SME hotel financial performance of the current period. These results indicate that investment in structural capital, such as, databases and processes, and, the long-term relationships with key stakeholders as employees and customers contribute to future financial performance of hotels. Findings also reveal that the interaction between IC components enhance hotel's financial performance.

This study contributes to the IC and hotel's literature by enhancing: i) the importance of each of components of IC components for the SME hotel financial performance; ii) the impact of the interrelationships between IC components on the SME hotel financial performance; iii) the importance of the methodology, using dynamic panel data models, to capture the dynamic nature of the relationships between IC components and SME hotel financial performance.

The current paper is structured as follows: Section 2 presents the theoretical framework and hypothesis development; Section 3 describes the methodology; Section 4 and Section 5 presents the results discussion; and Section 6 presents the conclusion and implications of the study.

\section{Literature review and hypotheses development}

\subsection{Intellectual capital and tourism industry}

The tourism industry is considered one of the largest and most dynamic industries in the world (Wang, 2015), in which the supply side of tourism must constantly adapt to the tourists demands (Weiermair, 2006), being a powerful generator of innovation (Omerzel and Jurdana, 2016).

Previous studies have shown the importance of IC in the hotel industry (Engström et al., 2003). IC is a fast-evolving concept (Ilyin, 2014; Mehralian et al., 2012) that has been capturing the attention of researchers and practitioners over the last two decades. It is a multidisciplinary and an interdisciplinary concept (Bontis, 1999; Marr and Chatzkel, 2004; Morariu, 2014). Consequently, due to different backgrounds and perspectives amongst researchers, there is no generally accepted definition of IC (Choong, 2008 Mehralian et al., 2012; Mondal and Ghosh, 2012; Morariu, 2014; Scafarto et al., 2016). Considering the current study's purpose, IC is defined as the knowledge-based activities and processes which contributes to firms' innovation, value creation, competitive advantages and future benefits by adding value for firms' stakeholders.

The synergetic value of IC is rooted in the interaction between its different components (Bontis et al., 2015; Sydler et al., 2014), i.e., human capital (employees' talent, skills and expertise), structural capital (organizational capabilities, culture, processes, patents, copyrights, trademarks, databases) and relational capital (creation and maintenance of relationships with stakeholders). The three-dimensional classification of IC provides the clearest and the least ambiguous categorization of IC (Sydler et al., 2014). According to Zeglat and Zigan (2014) it is not clear how the different IC components contribute for hotel's financial performance. Therefore, below, we present a brief description of each of components of IC as well as its role in the tourism industry, particularly, in the hotel sector based in previous studies.

Human capital is considered one of the core dimensions of IC and the most important firm's asset since it is the source of firm's strategy renewal, creativity, innovation capacity and, consequently sustains a major competitive advantage (Chi et al., 2016; O'Sullivan and Schulte, 2007; Bontis et al., 2007; Bontis, 1998; Brooking, 1997; Edvinsson and Malone, 1997; Nonaka and Takeuchi, 1995). Based on the employees' talent and skills (Ghosh and Mondal, 2009; Cater and Cater, 2009, Sydler et al., 2014; Tsakalerou, 2015; Ilyin, 2014), human capital provides uniqueness to the firms (O'Sullivan and Schulte, 2007) in the development of added value of goods to reach key stakeholders' loyalty (Bontis et al., 2007; Ghosh and Mondal, 2009; Cabrita and Bontis, 2008).

Structural capital remains in the firm after employees have left (Cabrita and Bontis, 2008; St-Pierre and Audet, 2011; Nazari and Herremans, 2007; Bontis et al., 2015; Curado, 2008; Stewart, 1997). It comprises the organizational capabilities, culture, processes, patents, copyrights, trademarks, databases, and so on (Ahangar, 2011; Denicolai et al., 2015, Janosevic and Dzenopoljac, 2012, Johnson, 1999). Structural capital supports and empowers human capital (Lee and Mohammed, 2014; Curado et al., 2011; Edvinsson, 1997; Tsakalerou, 2015; Ilyin, 2014; Bontis, 1998; Díez et al., 2010), which is a vital factor to structural capital development (Nazari and Herremans, 2007) and to reach its full potential in the firm's value creation and performance (Lee and Mohammed, 2014; St-Pierre and Audet, 2011; Sveiby, 1997; Bontis, 1998). Structural capital and human capital are interdependent and interact in the creation of IC (Cabrita and Bontis, 2008). Structural capital is also pointed as the supporting infrastructure for the establishment of external relationships (Molodchik et al., 2014; Schiuma and Lerro, 2008).

Relational capital is the ability of firms to create value through complex relationships with external stakeholders (Tsakalerou, 2015; Cabrita and Bontis, 2008; Meles et al., 2016; Joshi et al., 2013; Sydler 
et al., 2014). Relational capital is the most difficult IC dimension to develop since, at a some extent, it is outside of firm's core (Bontis, 1998; Scafarto et al., 2016). It enhances the human and structural capital's interaction with the stakeholders and influences stakeholders' perceptions of the firm (Cabrita and Bontis, 2008; Ting and Lean, 2009; Meles et al., 2016; Bontis et al., 2015). Examples of this are brand loyalty, market image, commercial power and reputation (Janosevic and Dzenopoljac, 2012; Ting and Lean, 2009; Joshi et al., 2013). Relational capital is knowledge embedded in the identification, development and maintenance of external relationships (Joshi et al., 2013; Ordoñez de Pablos, 2004; Bontis, 1999). Moreover, this capital allows firms to access knowledge and resources embedded within and derived from the network of relationships (Chang et al., 2008; Bontis, 1998; Edvinsson and Malone, 1997; Stewart, 1997; Meles et al., 2016). The relational capital allows firms to develop databases with information of external stakeholders in order to anticipate and develop future firm's strategies (Saeed et al., 2016). Having a better understanding of their external stakeholders will help firms to develop and produce products (Ordoñez de Pablos, 2004) in order to satisfy and build strong and lasting relationships with them (Ilyin, 2014; Meles et al., 2016). According to Saint-Onge (1996), IC process develops through flows, i.e., the increase in relational capital is a consequence of increase of human and structural capital and, in turn, the growth of relational capital will lead to the growth of financial capital.

\subsection{Intellectual capital and hotel financial performance}

IC literature lacks studies in tourism industry, since the majority of the studies in the services industry have mainly focused on financial and insurance sectors (Alhassan and Asare, 2016; Curado, 2008; Isanzu, 2016; Joshi et al., 2013; Kamath, 2007; Meles et al., 2016; Mondal and Ghosh, 2012; Ousama and Fatima, 2015; Soriya and Narwal, 2015; Ting and Lean, 2009; Yalama and Coskun, 2007; Kweh et al., 2014; Sherif and Elsayed, 2016). According to Engström et al. (2003), employees and organizational knowledge are the key elements for the success of hotels management, those authors concluded that the components of IC human capital and structural capital assure the service quality in hotels industry and are capitalized through the relationships established with key stakeholders (Rudez and Mihalic, 2007).

Bontis et al. (2015) analysed the relationship between IC and financial performance of Serbian hotels sector for the period between 2009 and 2012. The authors concluded that physical, financial, human and structural capital affects positively the hotel financial performance. Nevertheless, these authors realized that the financial performance of the hotels sector in Serbia is predominantly influenced by physical and financial capital. A common critique is that VAIC $^{\text {тм }}$ fails in measuring relational capital. In other study, Kim et al. (2012), using 13 upperupscale hotels in Korea stated that structural capital and relational capital directly and positively affect hotel financial performance, whereas human capital only indirectly affects hotel financial performance through. Omerzel and Jurdana (2016) performed a questionnaire survey to 2800 Slovenian and 1700 Croatian SME hotels in the tourism industry in order to verify the influence of IC on firm's innovation and growth. The authors used market share and profitability to measure growth. Results indicated that IC positively affects hotel's growth. Thus, survival in market competition and long-term development of hotel firms is ensured by constant investment in IC components and their efficient use. Following the previous studies, we argue that each of the components of IC as well as the interaction between IC components increase SME hotel financial performance. Therefore, we formulate the following hypotheses:

H1. Human capital positively impacts on SME hotel financial performance

H2. Structural capital positively impacts on SME hotel financial performance
H3. Relational capital positively impacts on SME hotel financial performance

H4. The Interrelationships between IC components positively impact on SME hotel financial performance

\section{Data, variables and method}

\subsection{Database}

The data used in this paper come from Amadeus database, which is a database of comparable financial and business information on firms of 43 European countries. Amadeus is published by Bureau van Dijk/ Moody's Analytics, including firm-level accounting data in standardized financial format comprising balance sheet items, profit and loss income statement items.

In the current study, hotels were selected according to the NACE code classification (Classification of Economic Activities in the European Union) for (I55.1) Hotels and similar accommodation. The SME hotels were selected according to the European Union recommendation L124/36 (2003/361/CE), in which a firm is considered a small and medium-sized enterprise if it meets at least two of the following three criteria: (i) it has fewer than 250 employees; (ii) its assets are valued at under 43 million Euros; and (iii) its business volume is under 50 million Euros. This study gathered data for the period between 2007 and 2015. The initial sample is composed by 1731 Portuguese SME hotels. After removing firms without data for at least 3 consecutive years, the final sample consisted of 934 Portuguese SME hotels.

The study uses an unbalanced panel data, in which the number of firm-years varies between 3 and 9. Therefore, we follow the suggestions of Guariglia (2008), Bond et al. (2003) and Cummins et al. (2006) in order to mitigate potential survivor bias by allowing the entrance and exit of firms. We trimmed the data at one percent tails in order to control the potential effects of outliers, which may derive from particular events, such as large mergers, errors in coding or extraordinary firms' shocks (Guariglia, 2008).

\subsection{Estimation method and variable measurement}

Due to the dynamic characteristics of the variables in this study, we use a Generalized Method of Moments (GMM) proposed by Blundell and Bond (1998), which considers a system of variables in levels and first differences. The instruments, for the variables in first differences, are presented at level, whereas for the variables at level, the instruments are presented in first differences. Valid and relevant instruments should be correlated with endogenous regressors and orthogonal to the errors. The efficiency of this estimator lies in the possibility to control correlation errors over time and heteroscedasticity across firms. The validity of the dynamic system GMM estimator is subject to two conditions: 1) the validity of instruments; and 2) no evidence for secondorder error autocorrelation.

In order to test the first condition, we use the Hansen test (Hansen $\left(\chi^{2}\right)$ ) for overidentifying restrictions, which under the null hypothesis of instruments validity, is distributed as a chi-square $\left(\chi^{2}\right)$ with degrees of freedom equal to the number of overidentifying restrictions, i.e., the number of instruments less the number of parameters. Rejecting the null hypothesis, it is concluded that the instruments are not valid, i.e., do not satisfy the required orthogonality conditions. For the second condition, we test for second-order autocorrelation $(m 2(\mathrm{~N}(0,1)))$, where the null hypothesis indicates there is no second-order autocorrelation. In the case of not rejecting the null hypothesis for the Hansen and second-order autocorrelation tests, we conclude that the GMM system (1998) estimator is valid and robust. This study uses a two-step procedure with the correction proposed by Windmeijer (2005), which provides more accurate inference of the two-step 
procedure especially for the GMM system (1998) estimator (Roodman, 2009).

We use the IC components in the current and previous period since IC investments, namely in the IC components considered in this study, i.e., human capital, structural capital and relational capital, may not produce an immediately effect on hotel financial performance. Furthermore, considering that the lack of financial resources is a main constrain for small and medium-sized enterprises to innovate (Iammarino et al., 2009; Savignac, 2008), we include the variable leverage in our models, which is the principal external financing source for small and medium-sized enterprises. SME hotel age and size were added to the model as control variables.

Next, we present our estimation models:

$$
\begin{aligned}
\operatorname{ROA}_{i, t}= & \propto_{0}+\beta_{1} \text { ROA }_{i, t-1}+\beta_{2} \operatorname{HCap}_{i, t}+\beta_{3} \operatorname{SCap}_{i, t}+\beta_{4} \operatorname{RCap}_{i, t} \\
& +\beta_{5} \operatorname{HCap}_{i, t-1}+\beta_{6} \operatorname{SCap}_{i, t-1}+\beta_{7} \operatorname{RCap}_{i, t-1}+\beta_{8} \operatorname{Tlev}_{i, t} \\
& +\beta_{9} A G E_{i, t}+\beta_{10} \operatorname{SIZE}_{i, t}+\beta_{11} D c_{08 ; 09}+\eta_{i}+\varepsilon_{i, t}
\end{aligned}
$$

As previously mentioned, the relevance of IC components to the hotel financial performance does not only refer to the individual contribution of each component but also the interaction between them. Therefore, the effect of the interaction of IC components on hotel financial performance was considered in the following model:

$$
\begin{aligned}
\operatorname{ROA}_{i, t}= & \propto_{0}+\beta_{1} \operatorname{ROA}_{i, t-1}+\beta_{2} \operatorname{HCap}_{i, t}+\beta_{3} \operatorname{SCap}_{i, t}+\beta_{4} \operatorname{RCap}_{i, t} \\
& +\beta_{5} \operatorname{HCap}_{i, t}{ }^{*} \operatorname{Cap}_{i, t}+\beta_{6} \operatorname{HCap}_{i, t}{ }^{*} \operatorname{RCap}_{i, t}+\beta_{7} \operatorname{SCap}_{i, t}{ }^{*} \operatorname{Cap}_{i, t} \\
& +\beta_{8} \operatorname{Tlev}_{i, t}+\beta_{9} A E_{i, t}+\beta_{10} \operatorname{SIZE}_{i, t}+\beta_{11} \operatorname{Dc}_{08 ; 09}++\eta_{i}+\varepsilon_{i, t}
\end{aligned}
$$

where: $\eta_{i}$ are non-observable individual effects; and $\varepsilon_{i, t}$ is the error. The variables used in this study and measurement are depicted in Table 1.

\section{Empirical results}

\subsection{Descriptive statistics and correlation matrix}

The descriptive statistics for the sample is depicted in Table 2.

For the period of analysis (2007-2015), it can be noticed that financial performance, measured by the variable $R O A_{i, t}$, presents a positive mean score of 0.64 and a standard deviation of 0.87 , suggesting that the profitability of Portuguese SME hotels present some volatility. Regarding the IC components, the average values suggest, higher level of human capital $\left(\mathrm{HCap}_{i, t}\right)$ and structural capital $\left(\operatorname{SCap}_{i, t}\right)$ than relational capital $\left(R C a p_{i, t}\right)$. Regarding the average value of age $\left(A G E_{i, t}\right)$ suggests that hotels in average are 27 years old ${ }^{1}$ and the average value of size $\left(S I Z E_{i, t}\right)$ indicates that hotels in average present 1.1 million Euros ${ }^{2}$ (calculated based on total assets). Also, the average ratio of total leverage $\left(\right.$ TLev $\left._{i, t}\right)$ is about $48 \%$, suggesting the dependence on debt for hotels to fund their investments and activities. The correlation and magnitude of the variables are presented in the correlation matrix (see Table 3).

The correlation matrix shows a significant correlation among the most pairs of variables. The problems of endogeneity between independent variables are relevant for correlation coefficients above $30 \%$ (Gujarati and Porter, 2010). This is the case between the pairs $S I Z E_{i, t}$ and $R O A_{i, t}$ of the previous period, SIZE $E_{i, t}$ and HCap $_{i, t}, S_{Z} E_{i, t} S C a p_{i, t}$ and

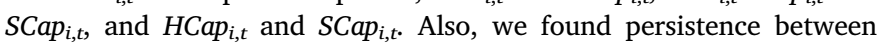
$R O A_{i, t}$ in the current period and $R O A_{i, t-1}$ in the previous period. Therefore, following the suggestion of Blundell and Bond (1998), we

\footnotetext{
${ }^{1}$ Calculated as the inverse function of natural logarithm. The mean of $e^{3.3} \approx 27 \mathrm{AGE}=3.3$ (see Table 2 ). By applying the inverse function of natural logarithm,

${ }^{2}$ Calculated as the inverse function of natural logarithm. The mean of

\begin{tabular}{|c|c|}
\hline Variable & Measurement \\
\hline \multicolumn{2}{|l|}{ Dependent variables } \\
\hline Return on Assets $\left(R O A_{i, t}\right)$ & Ratio of net profits to total assets at year $t$ \\
\hline \multicolumn{2}{|l|}{ Independent variables } \\
\hline $\begin{array}{l}\text { Return on Assets at } t-1 \\
\qquad\left(R O A_{i, t-1}\right)\end{array}$ & Ratio of net profits to total assets at year $t-1$ \\
\hline \multicolumn{2}{|l|}{ Intellectual Capital Dimensions } \\
\hline Human Capital $\left(\mathrm{HCap}_{i, t}\right)$ & Natural logarithm of staff costs \\
\hline Structural Capital $\left(S C a p_{i, t}\right)$ & Working capital turnover \\
\hline Relational Capital $\left(R C a p_{i, t}\right)$ & Revenues growth \\
\hline \multicolumn{2}{|c|}{ Interaction Between Intellectual Capital Dimensions } \\
\hline $\begin{array}{l}\text { Human Capital * Structural } \\
\text { Capital }\left(\operatorname{HCap}_{i, t} *\right. \\
\text { SCapi, } t)\end{array}$ & Human capital multiplied by structural capital \\
\hline $\begin{array}{l}\text { Human Capital * Relational } \\
\text { Capital }\left(\operatorname{HCap}_{i, t} *\right. \\
\left.\operatorname{RCap}_{i, t}\right)\end{array}$ & Human capital multiplied by relational capital \\
\hline $\begin{array}{l}\text { Structural Capital * } \\
\text { Relational Capital } \\
\left(\operatorname{SCap}_{i, t}{ }^{*} \operatorname{RCap}_{i, t}\right)\end{array}$ & Structural capital multiplied by relational capital \\
\hline \multicolumn{2}{|l|}{ Control Variables } \\
\hline \multicolumn{2}{|l|}{ Total Leverage $\left(\right.$ TLev $\left._{i, t}\right)$} \\
\hline Size $\left(S I Z E_{i, t}\right)$ & Natural logarithm of total assets \\
\hline Age $\left(A G E_{i, t}\right)$ & $\begin{array}{l}\text { Natural logarithm of the number of years of } \\
\text { existence of the firm }\end{array}$ \\
\hline Dummy Crisis $\left(D c_{08: 09}\right)$ & $\begin{array}{l}\text { Dummy representing crisis period. It assumes the } \\
\text { value of } 1 \text { if the year is equal to } 2008 \text { or } 2009 \text {, and } \\
\text { the value of } 0 \text { for the remaining years in study }\end{array}$ \\
\hline
\end{tabular}
$e^{7} \approx 1100$ SIZE $=7$ (see Table 2). By applying the inverse function of natural logarithm, $10^{3} \approx 1100000$. Since the values are in thousand Euros, the value 1100 is multiplied by $10^{3}, 1100 \times 10^{3} \approx 1100000$.
}

Table 1

Variables and measurement.

Table 2

Descriptive statistics of the sample.

\begin{tabular}{lllll}
\hline Variables & Observations & Mean & Median & SD \\
\hline ROA $_{i, t}$ & 6189 & 0.64 & 0.38 & 0.87 \\
CCap $_{i, t}$ & 5876 & 5 & 5 & 1.1 \\
SCap $_{i, t}$ & 4852 & 4.5 & 4.6 & 1.8 \\
CCap $_{i, t}$ & 5765 & 0.061 & 0.021 & 0.27 \\
TLev $_{i, t}$ & 6269 & 0.48 & 0.48 & 0.27 \\
AGE $_{i, t}$ & 6269 & 3.3 & 3.3 & 0.47 \\
SIZE $_{i, t}$ & 6023 & 7 & 7.1 & 1.4 \\
\hline
\end{tabular}

applied the GMM system (1998) dynamic estimator, which is more appropriate for this study than the GMM (1991) estimator. According to the results of the Hansen test and second-order autocorrelation test, we cannot reject the null hypothesis in both tests for all estimations in this study. Therefore, we do not reject the validity of the restrictions of the instruments used and we do not reject the hypothesis of the existence of second-order autocorrelation for the estimated models. Thus, the results of the GMM system (1998) dynamic estimator are valid and open to interpretation.

\subsection{Intellectual capital and firms' financial performance}

The results of GMM system (1998) for Models (1) and (2) are presented in Table 4.

The results of Eq. (1) show that profitability $\left(R O A_{i, t-1}\right)$ in the previous period, human capital $\left(H_{C a p}, t\right)$ in the current period, structural capital $\left(\operatorname{SCap}_{i, t}\right)$ in the current period, relational capital $\left(\operatorname{RCap}_{i, t}\right)$ in the current period, structural capital $\left(S \operatorname{Cap}_{i, t-1}\right)$ in the previous period, relational capital $\left(R C a p_{i, t-1}\right)$ in the previous period, leverage (TLev $\left.{ }_{i, t}\right)$ and age $\left(A G E_{i, t}\right)$ have a positive and significant relationship with $R O A_{i, t}$, whereas size $\left(S I Z E_{i, t}\right)$ has a $R O A_{i, t}$ significant negative relationship with $R O A_{i, t}$.

The results of Eq. (2) reveal that human capital $\left(\operatorname{HCap}_{i, t}\right)$ in the current period, structural capital $\left(S_{C a p_{i, t}}\right)$ in the current period, 
Table 3

Correlation matrix.

\begin{tabular}{|c|c|c|c|c|c|c|c|c|}
\hline & $R O A_{i, t}$ & $R O A_{i, t-1}$ & $\mathrm{HCap}_{i, t}$ & $\operatorname{SCap}_{i, t}$ & $R \operatorname{Cap}_{i, t}$ & $\operatorname{TLev}_{i, t}$ & $A G E_{i, t}$ & $S I Z E_{i, t}$ \\
\hline$R O A_{i, t}$ & 1.0000 & & & & & & & \\
\hline$R O A_{i, t-1}$ & $0.9111^{*}$ & 1.0000 & & & & & & \\
\hline$H_{C a p}{ }_{i, t}$ & $-0.0908^{*}$ & $-0.0965^{*}$ & 1.0000 & & & & & \\
\hline $\operatorname{SCap}_{i, t}$ & $-0.2557^{*}$ & $-0.2439 *$ & $0.4999 *$ & 1.0000 & & & & \\
\hline $\operatorname{RCap}_{i, t}$ & 0.0069 & $-0.0731 *$ & $-0.0787^{*}$ & -0.0301 & 1.0000 & & & \\
\hline $\operatorname{TLev}_{i, t}$ & -0.0358 & -0.0769 & 0.0351 & 0.0423 & -0.0233 & 1.0000 & & \\
\hline$A G E_{i, t}$ & $-0.0622^{*}$ & $-0.0602 *$ & $0.1788^{*}$ & $0.0829 *$ & $-0.0738^{*}$ & $-0.1851^{*}$ & 1.0000 & \\
\hline$S I Z E_{i, t}$ & $-0.5161 *$ & $-0.5138^{*}$ & $0.6439 *$ & $0.6161^{*}$ & -0.0104 & $0.0791 *$ & $0.1030 *$ & 1.0000 \\
\hline
\end{tabular}

Note: * Statistical significance at $1 \%$.

Table 4

Estimation results: GMM system (1998).

\begin{tabular}{|c|c|c|}
\hline \multirow[t]{2}{*}{ Independent variables } & \multicolumn{2}{|c|}{ Dependent variable: $R O A_{i, t}$} \\
\hline & Model (1) & Model (2) \\
\hline$R O A_{i, t-1}$ & $\begin{array}{l}0.47446^{* * *} \\
(0.02663)\end{array}$ & $\begin{array}{l}0.52755^{* * *} \\
(0.01532)\end{array}$ \\
\hline $\operatorname{HCap}_{i, t}$ & $\begin{array}{l}0.19125^{* * *} \\
(0.05217)\end{array}$ & $\begin{array}{l}0.31973 * * * \\
(0.04283)\end{array}$ \\
\hline $\operatorname{SCap}_{i, t}$ & $\begin{array}{l}0.01940^{* * *} \\
(0.00766)\end{array}$ & $\begin{array}{l}0.15056^{* * *} \\
(0.02838)\end{array}$ \\
\hline$R \operatorname{Cap}_{i, t}$ & $\begin{array}{l}0.37991 * * * \\
(0.03579)\end{array}$ & $\begin{array}{l}0.23990 * * \\
(0.11411)\end{array}$ \\
\hline $\mathrm{HCap}_{i, t-1}$ & $\begin{array}{l}-0.03423 \\
(0.03748)\end{array}$ & \\
\hline $\operatorname{SCap}_{i, t-1}$ & $\begin{array}{l}0.01918 * * * \\
(0.00269)\end{array}$ & \\
\hline$R C a p_{i, t-1}$ & $\begin{array}{l}0.06810^{* *} \\
(0.02739)\end{array}$ & \\
\hline $\operatorname{HCap}_{i, t} * \operatorname{SCap}_{i, t}$ & & $\begin{array}{l}0.02535^{* * *} \\
(0.00585)\end{array}$ \\
\hline $\operatorname{HCap}_{i, t}{ }^{*} \operatorname{RCap}_{i, t}$ & & $\begin{array}{l}0.06826^{* *} \\
(0.02679)\end{array}$ \\
\hline $\operatorname{SCap}_{i, t}{ }^{*} \operatorname{RCap}_{i, t}$ & & $\begin{array}{l}0.06826^{* * *} \\
(0.01316)\end{array}$ \\
\hline$T L e v_{i, t}$ & $\begin{array}{l}0.11566^{* * *} \\
(0.02117)\end{array}$ & $\begin{array}{l}0.15267 * * * \\
(0.01481)\end{array}$ \\
\hline$A G E_{i, t}$ & $\begin{array}{l}0.02829 * * \\
(0.01909)\end{array}$ & $\begin{array}{l}0.10759 * * * \\
(0.03071)\end{array}$ \\
\hline$S I Z E_{i, t}$ & $\begin{array}{l}-0.25218^{* * *} \\
(0.02461)\end{array}$ & $\begin{array}{l}-0.27108^{* * *} \\
(0.01746)\end{array}$ \\
\hline$D c_{08: 09}$ & $\begin{array}{l}-0.00864 \\
(0.00862)\end{array}$ & $\begin{array}{l}-0.00248 \\
(0.00775)\end{array}$ \\
\hline CONS & $\begin{array}{l}1.14484 * * * \\
(0.11775)\end{array}$ & $\begin{array}{l}0.05630 \\
(0.19329)\end{array}$ \\
\hline Observations & 3168 & 3714 \\
\hline Firms & 727 & 807 \\
\hline$F$ & $66264 * * *$ & $9756.09 * * *$ \\
\hline Hansen $\left(\chi^{2}\right)$ & 67.10 & 89.42 \\
\hline$m 1(\mathrm{~N}(0,1))$ & $-2.480 * * *$ & $-3.438^{* * *}$ \\
\hline$m 2(\mathrm{~N}(0,1))$ & -1.153 & -1.050 \\
\hline
\end{tabular}

Notes: 1. CONS is the constant of the regressions. 2. Standard errors in parentheses. 3. $* * *$ significant at $1 \%$ level and $* *$ significant at $5 \%$ level.

relational capital $\left(R_{C a p}{ }_{i, t}\right)$ in the current period, the interaction between the IC components, leverage $\left(T L e v_{i, t}\right)$ and age $\left(A G E_{i, t}\right)$ have a positive and significant relationship with $R O A_{i, t}$, while, size $\left(S I Z E_{i, t}\right)$ has a significant $R O A_{i, t}$ negative relationship with $R O A_{i, t}$.

\section{Discussion of the empirical results}

Results from Eqs. (1) and (2) reveal that SME hotel financial performance in the previous period $\left(\mathrm{ROA}_{i, t-1}\right)$ has a positive impact on SME hotel financial performance in the current period $\left(\mathrm{ROA}_{i, t}\right)$, which allows to conclude that financial performance is persistent in SME hotels.

The IC dimensions, i.e., human capital $\left(\mathrm{HCap}_{i, t}\right)$, structural capital
$\left(\mathrm{SCap}_{i, t}\right)$ and relational capital $\left(\mathrm{RCap}_{i, t}\right)$ in the current period, positively impact on SME hotel financial performance in both Eqs. (1) and (2). Therefore, we cannot reject the formulated hypotheses H1, H2, H3. Results corroborate the findings of Bontis et al. (2015), Kim et al. (2012), and Omerzel and Jurdana (2016).

Relational capital, human capital and structural capital assume importance for the success of SME hotels, which according to Engström et al. (2003) are the basis of service quality in the hotels sector. In fact, regarding the equation ( 1 ), the effect of relational capital $(\beta=0.38$, Table 4) presents a superior relative magnitude in comparison to the effects of human capital ( $\beta=0.191$, Table 4$)$ and structural capital ( $\beta=0,0194$, Table 4$)$. Therefore, the superior relative magnitude of the effect of relational capital suggests that this component contributes more than the other components of IC to the financial performance of SME hotels. This result suggests that SME hotel financial performance is enhanced by the establishment and maintenance relationships with key stakeholders. In fact, the relational capital refers to the firm's capacity to cooperate with external stakeholders, using the human capital and structural capital capacities. In this context, the relationships with the customers influencing their satisfaction and loyalty as well as the importance of the relationships with other stakeholders in the value channel, seem to contribute positively to SME hotel financial performance. Therefore, the results of the current study seem to corroborate the argument of Saint-Onge (1996) that IC is a process that develops through flows, i.e., the increase in relational capital is a consequence of increase of human and structural capital and, in turn, the growth of relational capital will lead to the growth of financial capital for hotel firms.

Additionally, human capital is a component of IC with an important effect on the SME hotel financial performance, corroborating the results of previous studies which enhance the importance of human resources for hotel financial performance (Laing et al., 2010; Bontis et al., 2015; Adeola, 2016). In fact, the tourism industry depends strongly on the skills and knowledge of the employees (Ognjanović, 2017). Finally, structural capital is the component of IC with minor effect on SME hotel financial performance. This result corroborates the result obtained by Sharabati et al. (2013) for the Jordanian tourism sector. However, previous studies identified a positive and strong relationship between structural capital and hotel's financial performance (Laing et al., 2010; Bontis et al., 2015), which is explained by the importance of the means that structural capital proportionate to employees to achieve efficiency and efficacy.

In Eq. (1), we test the impact of the IC dimensions in the previous period, i.e., human capital $\left(\mathrm{HCap}_{i, t-1}\right)$,structural capital $\left(\mathrm{SCap}_{i, t-1}\right)$ and relational capital $\left(\mathrm{RCap}_{i, t-1}\right)$,on the SME hotel financial performance. Results indicate that structural capital and relational capital in the previous period positively affect SME hotel financial performance in the current period, while for the case of human capital in the previous period, it was not found a statistical significant relationship. These results indicate that past investments in structural capital, such as, databases and processes, as well as the maintenance of the relationships created in the past with the stakeholders are valorous to the future SME 
hotel financial performance. However, the results suggest that the investment in human capital, in the past, does not influence the financial performance. Therefore, these results show that the past levels of structural capital and relational capital are important for SME hotel financial performance.

In order to analyse the impact of the interrelationships between IC components and SME hotel financial performance, in Eq. (2) we substitute the IC dimensions in the previous period, i.e., $\mathrm{HCap}_{i, t-1}$, $S C a p_{i, t-1}$ and $R C a p_{i, t-1}$, by the interaction terms of the IC dimensions, i.e., $\operatorname{Cap}_{i, t}{ }^{*} \operatorname{SCap}_{i, t}, \operatorname{HCap}_{i, t}{ }^{*} R \operatorname{Cap}_{i, t}$ and $\operatorname{SCap}_{i, t}{ }^{*} R \operatorname{Cap}_{i, t}$, and the results reveal that the interaction between IC components enhance SME hotel financial performance and thereby, we cannot reject the formulated hypothesis H4. Therefore, the positive sign attributed to the coefficients of the interaction terms indicate that (1) human capital positively moderates the effect of structural capital and relational capital on SME hotel financial performance, (2) structural capital positively moderates the effect of human capital and relational capital on SME hotel financial performance and (3) relational capital positively moderates the effect of human capital and structural capital on SME hotel financial performance.

On the one hand, structural capital seems to support and empower human capital (Lee and Mohammed, 2014, Curado et al., 2011, Edvinsson, 1997, Tsakalerou, 2015, Ilyin, 2014, Bontis, 1998, Díez et al., 2010). This enhances the employees' capabilities to develop and offer solutions to customers' needs and, thereby, reaching customerś satisfaction and loyalty. Additionally, structural capital also appears to support the establishment of long-term relationships with stakeholders in order to satisfy and build strong and lasting relationships with them (Ilyin, 2014, Meles et al., 2016). On the other hand, relational capital enhances human capital and structural capital, strengthening the positive contribution of individual components of IC to SME hotel financial performance (Cabrita and Bontis, 2008, Ting and Lean, 2009, Meles et al., 2016, Bontis et al., 2015). The results of the current study corroborate the arguments of Kim et al. (2012) regarding the importance of relational capital for the current and future value of the organizations relationships with their customers. Given that hotels should carry out efforts to meet the customers' satisfaction in order to build customers' loyalty, hotels should invest in relational capital which in addition to reputation, brand management (i.e., structural capital) as well as employees' competence and motivation (human capital) generates value, and contributes to a sustainable performance (Kim et al., 2012; Kim and Lee, 2013).

The results of the remaining variables, i.e., age $\left(\mathrm{AGE}_{i, t}\right)$, size $\left(\operatorname{SIZE}_{i, t}\right)$, and leverage $\left(\operatorname{TLev}_{i, t}\right)$, have a similar influence on SME hotel financial performance on both Eqs. (1) and (2). Findings reveal that age impacts positively SME hotel financial performance. Given that age can be considered a proxy of firm's reputation (Diamond, 1989), the results suggested that the stakeholders seem to recognize the reputation that hotels have built over time. Therefore, the results of the current study suggest that the recognition of the stakeholders positively contributes to SME hotel financial performance. Aissa and Goaied (2016) verify a positive relationship between age and hotel financial performance. These authors argue that hotels take time to reach a high level of profitability, which requires investments in infrastructure and amenities.

The negative relationship between size and SME hotel financial performance might be due to scale effects or the seasonality, which is a characteristic of tourism industry, since empty beds produce no income. Several studies have identified a positive relationship between firm size and performance (Barros and Mascarenhas, 2005; Chen and Tseng, 2005; Chung and Kalnins, 2001; Israeli, 2002; Rodríguez and Cruz, 2007). Claver-Cortés et al. (2007) identified a positive relationship between size and hotel financial performance Kim and Lee (2013) argued that medium or large-sized hotels present greater levels of performance in comparison to smaller hotels. In spite of high rates of occupancy and great sales revenues presented by large hotels, they have a tendency to present lower levels of profitability. Thus, large hotels produce better revenues but worse financial performance (Chen, 2009; Zeglat and Zigan, 2014). Probably, the greater size of hotels implies more complex structures of management contributing to a diminished efficiency as well as financial performance (Zeglat and Zigan, 2014).

Leverage positively contributes to SME hotel financial performance and, thereby owners/managers seem to efficiently manage financial resources. In fact, considering that the SME hotels may depend on debt to fund their needs, it seems that this type of funds is managed efficiently and impacting positively on financial performance. The debt decision itself has an impact on firm financial performance. Debt can be used to obtain debt-tax shields in spite of the bankruptcy costs associated, therefore firms must balance debt shields with bankruptcy costs to take the debt decision. Furthermore, several studies show that small sized firms follow a pecking order in the selection of finance sources. After the exhaustion of retained earnings, firms choose to fund their needs raising debt that has inferior costs in comparison to equity issues. Therefore, SME hotels probably are dependent on debt to fund their current activities and investments, which generates added value for the firm, given the positive impact of this external financing source on SME hotel profitability. Because the interest paid for the debt is tax deductible, companies that increase Debt also can function as a corporate governance tool to discipline the managers' decision privileging the maximization of firm's value, in order to avoid the firms insolvency, which would imply personal lose for managers and the loss of personal fortunes (Jensen and Meckling, 1976).

\section{Conclusion}

Intellectual capital is a recognized foundation stone of firm's competitive advantage. Based on sample of 934 Portuguese SME hotels, this study analyses the effect of intellectual capital financial performance, for the period between 2007 and 2015. Resorting to panel data models, and using the GMM system (1998) dynamic estimator, empirical findings show that human capital, structural capital and relational capital positively impact on SME hotel financial performance. Human capital and structural capital knowledge appears to be key elements for the success of SME hotels and are the basis of service quality in the hotels sector. Furthermore, human and structural capital are capitalized by the establishment and maintenance of long-term relationships with key stakeholders, i.e., by strengthening the relational capital.

Structural capital and relational capital in the previous period positively influence SME hotel financial performance of the current period. These results also indicate that investments in structural capital, such as, databases and processes, are valorous to future SME hotel financial performance and, thereby it enhances the long-term relationships with key stakeholders. Moreover, the results show the persistence of financial performance, which means that financial performance of the past period is a positive influence on the financial performance for the current period. In this context, these findings suggest that investments made in structural capital and relational capital can positively impact on the financial performance of the current period of SME hotels. Additionally, these results reveal that the interaction between IC dimensions enhance SME hotel financial performance. In fact, it is worth to highlight that the interrelationships between IC components impact positively on IC that means that SME hotels can improve their financial performance investing in each components of IC, which will create value, considering the scale effect obtained on the basis of the interrelationships between IC components. Furthermore, the return on investment in IC components takes time, which seems to be reflected in the positive relationship between age and financial performance of SME hotels. The investments in IC take time to generate profitability and return, thus older SME hotels become more profitable than their young counterparts. It is worth to enhance that size has a negative impact on SME hotel financial performance, suggesting that larger hotels are less profitable, probably due to the loss of monitoring and control the 
management decision taking.

On the practical side, it is important that owners/managers closely manage hotel firms' intellectual capital, since it is a source of SME hotel value creation and financial performance. Some study limitations can be mentioned and addressed in future research. This study used financial proxies to measure IC dimensions. Therefore, it would be interesting to try different proxies for measuring IC dimensions, such as training and development expenses and marketing or advertising expenses. As it was not our purpose, we have not analysed the interaction between the lagged IC components. Thus, it could be considered in future studies in order to test if continuous investment in the interaction between IC components produces future benefits in terms of SME hotel financial performance. Finally, future studies could investigate other type of tourism industries, or replicate the study in other countries for comparison purposes, by using small and medium-sized enterprises as subject of analysis.

\section{Acknowledgements}

The authors are pleased to acknowledge financial support from Fundação para a Ciência e a Tecnologia: Zélia Serrasqueiro (grant UID/ ECO/04007/2013) and FEDER/COMPETE (POCI-01-0145-FEDER007659); Helena Alves (NECE - R\&D Centre funded by the Multiannual Funding Programme of R\&D Centres of FCT). Finally, the authors would like to sincerely thank the anonymous reviewers for their valuable comments and suggestions, which contributed to the improvement of the paper.

\section{References}

Adeola, O., 2016. Human capital development in the hospitality industry in Nigeria. Worldw. Hosp. Tour. Themes 8 (2), 149-157.

Ahangar, R.G., 2011. The relationship between intellectual capital and financial perfor mance: an empirical investigation in an Iranian company. Afr. J. Bus. Manage. 5 (1), 88-95.

Aissa, S.B., Goaied, M., 2016. Determinants of Tunisian hotel profitability: the role of managerial efficiency. Tour. Manage. 52, 478-487.

Alhassan, A.L., Asare, N., 2016. Intellectual capital and bank productivity in emerging markets: evidence from Ghana. Manage. Decis. 54 (3), 589-609.

Arnould, E.J., Price, L.L., Malshe, A., 2006. Toward a cultural resource-based theory of the customer. In: Lusch, R.F., Vargo, S.L. (Eds.), The Service-dominant Logic of Marketing: Dialog, Debate and Directions. Routledge, New York, pp. 320-333.

Barros, C.P., Mascarenhas, M.J., 2005. "Technical and allocative efficiency in a chain of small hotels". Int. J. Hosp. Manage. 24 (3), 415-436.

BdP, 2016. Análise sectorial do alojamento, restauração e similares -2011-2016, Banco de Portugal. E studos da Central de Balanços, Lisboa.

Blundell, R., Bond, S., 1998. Initial conditions and moment restrictions in dynamic panel data models. J. Econ. 87 (1), 115-143.

Bond, S., Elston, J., Mairesse, J., Mulkay, B., 2003. Financial factors and investment in Belgium, France, Germany, and the United Kingdom: a comparison using company panel data. Rev. Econ. Stat. 85 (1), 153-165.

Bontis, N., Seleim, A., Ashour, A., 2007. Human capital and organizational performance: a study of Egyptian software companies. Manage. Decis. 45 (4), 789-801.

Bontis, N., Janosevic, S., Dzenopoljac, V., 2015. Intellectual capital in Serbia's hotel industry. Int. J. Contemp. Hosp. Manage. 27 (6), 1365-1384.

Bontis, N., 1998. Intellectual capital: an exploratory study that develops measures and models. Manage. Decis. 36 (2), 63-76.

Bontis, N., 1999. Managing organizational knowledge by diagnosing intellectual capital: framing and advancing the state of the field. Int. J. Technol. Manage. 18 (5-8), 433-462.

Brooking, A., 1997. Intellectual Capital: Core Asset for the Third Millennium Enterprise. Thomson Business Press, London.

Cabrita, M. d. R., Bontis, N., 2008. Intelectual capital and business performance in the Portuguese banking industry. Int. J. Technol. Manage. 43 (1-3), 212-237.

Cater, T., Cater, B., 2009. (In)tangible resources as antecedents of a company's competitive advantage and performance. J. East Eur. Manage. Stud. 14 (2), 186-209.

Chang, S.C., Chen, S.-S., Lai, J.-H., 2008. The effect of alliance experience and intellectual capital on the value creation of international strategic alliances. Omega-Int. J. Manage. Sci. 36 (2), 298-316.

Chen, H.M., Tseng, C.H., 2005. The performance of marketing alliances between the tourism industry and credit card issuing banks in Taiwan. Tour. Manage. 26 (1), $15-24$.

Chen, T.H., 2009. Performance measurement of an enterprise and business units with an application to a Taiwanese hotel chain. Int. J. Hosp. Manage. 28 (3), 415-422.

Chi, C.W., Lieu, P.T., Hung, K., Cheng, H.W., 2016. Do industry or firm effects drive performance in Taiwanese knowledge-intensive industries? Asia Pac. Manage. Rev.
21 (3), 170-179

Choong, K.K., 2008. "Intellectual capital: definitions, categorization and reporting models". J. Intell. Cap. 9 (4), 609-638.

Chung, W., Kalnins, A., 2001. Agglomeration effects and performance: a test of the Texas lodging industry. Strat. Manage. J. 22 (10), 969-988.

Claver-Cortés, E., Molina-Azorín, J.F., Pereira-Moliner, J., López-Gamero, M.D., 2007. Environmental strategies and their impact on hotel performance. J. Sustain. Tour. 15 (6), 663-679.

Constantin, J.A., Lusch, R.F., 1994. Understanding Resource Management: How to Deploy Your People, Products, and Processes for Maximum Productivity. The planning Forum, Oxford, Ohio.

Cummins, J., Hasset, K., Oliner, S., 2006. Investment behavior, observable expectations, and internal funds. Am. Econ. Rev. 96 (3), 796-810.

Curado, C., Henriques, L., Bontis, N., 2011. Intellectual capital disclosure payback. Manage. Decis. 49 (7-8), 1080-1098.

Curado, C., 2008. Perceptions of knowledge management and intellectual capital in the banking industry. J. Knowl. Manage. 12 (3), 141-155.

Díez, J.M., Ochoa, M.L., Prieto, M.B., Santidrián, A., 2010. Intellectual capital and value creation in Spanish firms. J. Intell. Cap. 11 (3), 348-367.

Denicolai, S., Ramusino, E.C., Sotti, F., 2015. The impact of intangibles on firm growth Technol. Anal. Strat. Manage. 27 (2), 219-236.

Diamond, D., 1989. Reputation acquisition in debt markets. J. Polit. Econ. 97 (4), 828-862.

Edvinsson, L., Malone, M., 1997. Intellectual Capital: Realizing Your Company's True Value by Finding Its Hidden Roots. Harper Collins, New York NY.

Edvinsson, L., 1997. Developing intellectual capital at Skandia. Long Range Plann. 30 (3), $320-331$.

Engström, T.E.J., Westnes, P., Westnes, F., 2003. Evaluating intellectual capital in the hotel industry. J. Intell. Cap. 4 (3), 287-303.

FitzPatrick, M., Davey, J., Muller, L., Davey, H., 2013. Value-creating assets in tourism management: applying marketing's service-dominant logic in the hotel industry. Tour. Manage. 36, 86-98.

Ghosh, S., Mondal, A., 2009. Indian software and pharmaceutical sector IC and financial performance. J. Intell. Cap. 10 (3), 369-388.

Guariglia, A., 2008. Internal financial constraints, external financial constraints, and investment choice: evidence from a panel of UK firms. J. Bank. Finance 32 (9), 1795-1809.

Gujarati, D., Porter, D. (Eds.), 2010. Essentials of Econometrics. McGraw-Hill International, New York.

INE, 2017. Empresas Em Portugal-2015. Instituto Nacional de Estatística, Lisboa.

Iammarino, S., Sanna-Randaccio, F., Savona, M., 2009. The perception of obstacles to innovation. Foreign multinationals and domestic firms in Italy. Revue d'Economie Industrielle 125, 75-104.

Ilyin, D.S., 2014. The impact of intellectual capital on companies` performance: evidence from emerging markets. Korporativnye Finansy 32 (4), 46-66.

Isanzu, J.N., 2016. The relationship between intellectual capital and financial performance of banks in Tanzania. Risus-J. Innov. Sustain. 7 (1), 28-38.

Israeli, A.A., 2002. Star rating and corporate affiliation: their influence on room price and performance of hotels in Israel. Int. J. Hosp. Manage. 21 (4), 405-424.

Janosevic, S., Dzenopoljac, V., 2012. Impact of intellectual capital on financial performance of serbian companies. Actual Probl. Econ. 133, 554-564.

Jensen, M.C., Meckling, W.H., 1976. Theory of the firm: managerial behavior, agency costs, and ownership structure. J. Financ. Econ. 3 (4), 305-360.

Johnson, W.H.A., 1999. An integrative taxonomy of intellectual capital: measuring the stock and flow of intellectual capital components in the firm. Int. J. Technol. Manage. 18 (5-8), 562-575.

Joshi, M., Cahill, D., Sidhu, J., Kansal, M., 2013. Intellectual capital and financial performance: an evaluation of the Australian financial sector. J. Intell. Cap. 14 (2), 264-285.

Kamath, G.B., 2007. The intellectual capital performance of the Indian banking sector. J. Intell. Cap. 8 (1), 96-123.

Kaufman, T.J., Weaver, P.W., Poynter, J., 1996. Success attributes of B\&B operators. Cornell Hotel Restaur. Adm. Q. 37 (4), 21-33.

Kim, T.T., Lee, G., 2013. "Hospitality employee knowledge-sharing behaviors in the relationship between goal orientations and service innovative behavior". Int. J. Hosp. Manage. 34, 324-337.

Kim, T., Kim, W.G., Park, S.S.-S., Lee, G., Jee, B., 2012. Intellectual capital and business performance: what structural relationships do they have in upper-upscale hotels? Int J. Tour. Res. 14 (4), 391-408.

Kweh, Q.L., Lu, W.-M., Wang, W.-K., 2014. Dynamic efficiency: intellectual capital in the Chinese non-life insurance firms. J. Knowl. Manage. 18 (5), 937-951.

Laing, G., Dunn, J., Hughes-Lucas, S., 2010. Applying the VAIC ${ }^{\mathrm{TM}}$ model to Australian hotels. J. Intell. Cap. 11 (3), 269-283.

Lee, S.P., Mohammed, S.I., 2014. Intellectual capital on listed agricultural firms' performance in Malaysia. Int. J. Learn. Intell. Cap. 11 (3), 202-221.

Liu, C.-H., 2017. Creating competitive advantage: linking perspectives of organization learning, innovation behavior and intellectual capital. Int. J. Hosp. Manage. 66, $13-23$.

Lusch, R.F., Vargo, S.L., 2006. Service-dominant logic: reactions, reflections and refinements. Market. Theory 6 (3), 281-288.

Lusch, R.F., Vargo, S.L., 2014. The Service-Dominant Logic of Marketing: Dialog Debate, and Directions. Routledge, London and New York.

Lusch, R.F., Vargo, S.L., O'Brien, M., 2007. Competing through service: insights from service-dominant logic. J. Retail. 83 (1), 5-18.

Macchiavelli, A., 2001. Tourist destinations as integrated systems. Tour. Rev. 56 (3/4), 6-11. 
Marr, B., Chatzkel, J., 2004. Intellectual capital at the crossroads: managing, measuring, and reporting of IC. J. Intell. Cap. 5 (2), 224-229.

Marzo, G., Scarpino, E., 2016. Exploring intellectual capital management in SMEs: an indepth Italian case study. J. Intell. Cap. 17 (1), 27-51.

Mehralian, G., Rasekh, H.R., Akhavan, P., Sadeh, M.R., 2012. The impact of intellectual capital efficiency on market value: an empirical study from iranian pharmaceutical companies. Iran. J. Pharm. Res. 11 (1), 195-207.

Meles, A., Porzio, C., Sampagnaro, G., Verdoliva, V., 2016. The impact of the intellectual capital efficiency on commercial banks performance: evidence from the US. J. Multinatl. Financ. Manage. 36, 64-74.

Molodchik, M.A., Shakina, E.A., Barajas, A., 2014. Metrics for the elements of intellectual capital in an economy driven by knowledge. J. Intell. Cap. 15 (2), 206-226.

Mondal, A., Ghosh, S.K., 2012. Intellectual capital and financial performance of Indian banks. J. Intell. Cap. 13 (4), 515-530.

Morariu, C.M., 2014. Intellectual capital performance in the case of Romanian public companies. J. Intell. Cap. 15 (3), 392-410.

Nazari, J.A., Herremans, I.M., 2007. Extended VAIC model: measuring intellectual capital components. J. Intell. Cap. 8 (4), 595-609.

Nonaka, I., Takeuchi, H., 1995. The Knowledge Creating Company. University Press, Melea Oxford.

O'Sullivan, K.J., Schulte Jr., W.D., 2007. Models for human capital management: human resource management of intellectual capital. Int. J. Learn. Intell. Cap. 4 (4), 453-466.

Ognjanović, J., 2017. Relations of intellectual capital components in hotel companies. Industrija 45 (2).

Omerzel, D.G., Jurdana, D.S., 2016. The influence of intellectual capital on innovativeness and growth in tourism SMEs: empirical evidence from Slovenia and Croatia Econ. Res.-Ekonomska Istrazivanja 29 (1), 1075-1090.

Ordoñez de Pablos, P., 2004. The importance of relational capital in service industry: the case of the Spanish banking sector. Int. J. Learn. Intell. Cap. 1 (4), 431-440.

Ousama, A.A., Fatima, A.H., 2015. Intellectual capital and financial performance of Islamic banks. Int. J. Learn. Intell. Cap. 12 (1), 1-15.

Poorani, A.A., Smith, D.R., 1995. Financial characteristics of bed-and-breakfast inns. Cornell Hotel Restaur. Adm. Q. 36 (5), 57-63.

Rodríguez, F.J.G., Cruz, Y.M.A., 2007. Relation between social-environmental responsibility and performance in hotel firms. Int. J. Hosp. Manage. 26 (4), 824-839.

Romer, P.M., 1986. Increasing returns and long-run growth. J. Polit. Econ. 94 (5), 1002-1037.

Roodman, D.M., 2009. A note on the theme of too many instruments. Oxford Bull. Econ. Stat. 71 (1), 135-158.

Rudez, H.N., Mihalic, T., 2007. Intellectual capital in the hotel industry: a case study from Slovenia. Int. J. Hosp. Manage. 26 (1), 188-199.

Saeed, S., Rasid, S.Z.A., Basiruddin, R., 2016. Relationship between intellectual capital and corporate performance of top Pakistani companies: an empirical evidence. Int. J Learn. Intell. Cap. 13 (4), 376-396.

Sainaghi, R., Baggio, R., 2014. Structral social capital and hotel performance: is there link? Int. J. Hosp. Manage. 37, 99-110.

Saint-Onge, H., 1996. Tacit knowledge: the key to the strategic alignment of intellectual capital. Strat. Leadersh. 24 (2), 10-14.

Savignac, F., 2008. Impact of financial constraints on innovation: what can be learned from a direct measure? Econ. Innov. New Technol. 17 (6), 553-569.

Scafarto, V., Ricci, F., Scafarto, F., 2016. "Intellectual capital and firm performance in the global agribusiness industry: the moderating role of human capital". J. Intell. Cap. 17 (3), 530-552.

Schiuma, G., Lerro, A., 2008. Intellectual capital and company's performance improvement. Meas. Bus. Excell. 12 (2), 3-9.

Sharabati, A., Radi, A., Nour, A., Durra, A., Moghrabi, K., 2013. The effect of intellectual capital on Jordanian tourism sector's business performance. Am. J. Bus. Manage. 2 (3), 210-221.

Sharma, A., Upneja, A., 2005. Factors influencing financial performance of small hotels in Tanzania. Int. J. Contemp. Hosp. Manage. 17 (6), 504-515.

Sherif, M., Elsayed, M., 2016. The impact of intellectual capital on corporate performance: evidence from the egyptian insurance market. Int. J. Innov. Manage. 20 (3).
Soriya, S., Narwal, K.P., 2015. Intellectual capital performance in Indian banks: a panel data analysis. Int. J. Learn. Intell. Cap. 12 (2), 103-121.

St-Pierre, J., Audet, J., 2011. Intangible assets and performance: analysis on manufacturing SMEs. J. Intell. Cap. 12 (2), 202-223.

Stewart, T.A., 1997. Intellectual Capital: the New Wealth of Organizations. Doubleday \& Co, New York N.Y.

Sveiby, K.E., 1997. The New Organizational Wealth: Managing and Measuring Knowledge-Based Assets. Berrett-Koehler, New York.

Sydler, R., Haefliger, S., Pruksa, R., 2014. Measuring intellectual capital with financial figures: can we predict firm profitability? Eur. Manage. J. 32 (2), 244-259.

Ting, I.W.K., Lean, H.H., 2009. "Intellectual capital performance of financial institutions in Malaysia". J. Intell. Cap. 10 (4), 588-599.

Tsakalerou, M., 2015. A meta-study of intellectual capital and firm performance: when the whole is more than the sum of its parts. Int. J. Learn. Intell. Cap. 2 (3), 287-299.

Tynan, C., McKechnie, S., 2009. Experience marketing: a review and reassessment. J. Market. Manage. 25 (5-6), 501-517.

Vargo, S.L., Lusch, R.F., 2008. Service-dominant logic: continuing the evolution. J. Acad. Market. Sci. 36 (1), 1-10

Vargo, S.L., Lusch, R.F., 2016. Institutions and axioms: an extension and update of service-dominant logic. J. Acad. Market. Sci. 44 (1), 5-23.

Wang, M.-C., 2015. Value relevance of Tobin's Q and corporate governance for the Taiwanese tourism industry. J. Bus. Ethics 130 (1), 223-230.

Weiermair, K., 2006. Product improvement or innovation: what is the key to success in tourism? In: OECD (Ed.), Innovation and Growth in Tourism. OECD, Paris, pp. 53-67.

Windmeijer, F., 2005. "A finite sample correction for the variance of linear efficient twostep GMM estimators”. J. Econ. 126 (1), 25-51.

Yalama, A., Coskun, M., 2007. Intellectual capital performance of quoted banks on the Istanbul stock exchange market. J. Intell. Cap. 8 (2), 256-271.

Zeglat, D., Zigan, K., 2014. Intellectual capital and its impact on business performance: evidences from the Jordanian hotel industry. Tour. Hosp. Res. 13 (2), 83-100.

Filipe Sardo $\mathrm{PhD}$ in Management, Assistant Professor at Universidade Europeia. The research interests are Intangible Assets, Intellectual Capital and Corporate Finance. He has published in Journals, such as Journal of Intellectual Capital and Journal of Small Business and Enterprise Development.

Zélia Serrasqueiro PhD in Management, Full Professor at University of Beira Interior an Researcher in CEFAGE-UBI. The research interests are Corporate Finance and Entrepreneurial Finance. She has published in various journals: Journal of Business Economics and Management, Entrepreneurship Theory \& Practice, Research Policy, Journal of Evolutionary Economics, Small Business Economics, International Journal of Hospitality Management Industrial and Corporate Change, International Journal of Hospitality Management, Journal of Business Research, Journal of Service Management, The Services Industries Journal, Management Research Review, Social Responsibility Journal, Review of Accounting and Finance.

Helena Alves is Associate Professor of Marketing at the Management and Economic Department and researcher at NECE, University of Beira Interior, Portugal. Her areas of expertise include Customer Satisfaction, Services marketing, Tourism marketing and Public and Nonprofit marketing having authored and co-authored several articles and book chapters on this themes. For some years she was coordinator of the marketing degree and later of the master degree. Her teaching experience includes degree, master and Ph.D levels, in Portugal and Spain (University of Extremadura, University of León and University of Valência). Currently, she is the editor of the International Review on Public and Nonprofit Marketing, and is also in the editorial review boards of several journals such as The Service Industries Journal, The Management Decision Journal, the Service Business Journal, the Journal of Business Research among other. She is responsible for the publications and vice president of the International Association on Public and Nonprofit Marketing. 